\title{
POLITICAL COMMUNICATION AND THINK TANKS IN SPAIN. STRATEGIES WITH THE MEDIA
}

\author{
Comunicación política y think tanks en España. \\ Estrategias con los medios de comunicación
}

Antonio Castillo-Esparcia, Sergio Guerra-Heredia and Ana Almansa-Martínez

Nota: Este artículo se puede leer en español en:

https://recyt.fecyt.es/index.php/EPI/article/view/59543

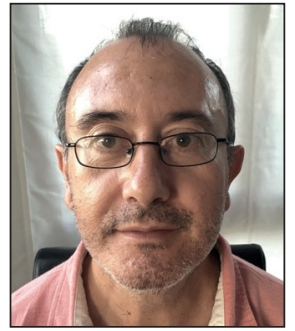

Antonio Castillo-Esparcia is a professor at the Facultad de Ciencias de la Comunicación de la Universidad de Málaga. PhD and graduate of the Universidad Autónoma de Barcelona (UAB); author of more than 130 national and international publications on public relations, strategic communication, lobbies and think tanks; co-director of the R\&D project of the Ministerio de Economía: Lobby and communication.

https://orcid.org/0000-0002-9751-8628

acastilloe@uma.es

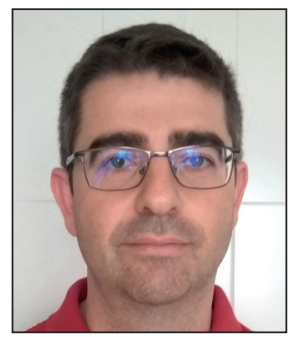

Sergio Guerra-Heredia is a researcher at the Universidad de Málaga (UMA). He holds a degree in Advertising and Public Relations from the UMA and is the author of publications on think tanks and their communication actions. Promoter of a project on the study and analysis of think tanks in Latin America and their communication strategies https://orcid.org/0000-0001-5324-6555

seguerr25@hotmail.com

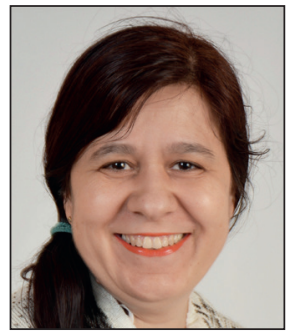

Ana Almansa-Martínez is a professor at the Facultad de Ciencias de la Comunicación at the Universidad de Málaga (UMA). PhD in Communication from the UMA and graduate of the Universidad Autónoma de Barcelona (UAB); author of over 100 national and international publications on communication management, public relations, political communication and ICT; co-director of the R\&D project of the Ministerio de Economía: Lobby and communication.

https://orcid.org/0000-0003-0256-6369

anaalmansa@uma.es

Universidad de Málaga, Facultad de Comunicación Campus de Teatinos, s/n. 29071 Málaga, Spain

\begin{abstract}
Think tanks have become increasingly important as political players in Spain having grown in both quantity and quality, and with greater social, political and communicative presence. This research analyses the presence of think tanks in Spanish main newspapers. Six principal general information newspapers and two economic information newspapers from 2012 to 2016 were analysed, using the content analysis method. Variables analysed include name and type of think tank, type of content (information or opinion) and communication technique used to give them journalistic presence. The results show that El país is the newspaper that provides more information about think tanks, and FAES is the think tank with the greatest presence in newspapers.
\end{abstract}

\section{Keywords}

Think tanks; Strategic communication; Political communication; Newspapers; Media. 


\section{Resumen}

Los think tanks han adquirido una creciente importancia como actores políticos en España con un aumento en número y en calidad, y con una mayor presencia social, política y comunicativa. Esta investigación analiza la presencia de los think tanks en los diarios de referencia de España. Para ello, se estudian los seis principales diarios de información general y los dos principales diarios de información económica en los años 2012 a 2106 . Se ha utilizado la técnica del análisis de contenido, revisando todo el contenido redaccional estructurado en variables como el nombre y tipo de think tank, el tipo de contenido (información u opinión) y la técnica de comunicación que le ha permitido tener presencia periodística. Los resultados muestran que el diario El país es el que más informaciones ofrece sobre los think tanks, y que el FAES es el que tiene mayor presencia periodística en los diarios.

\section{Palabras clave \\ Think tanks; Estrategias de comunicación; Comunicación política; Diarios; Periódicos.}

Castillo-Esparcia, Antonio; Guerra-Heredia, Sergio; Almansa-Martínez, Ana (2017). "Political communication and think tanks in Spain. Strategies with the media". El profesional de la información, v. 26, n. 4, pp. 706-713.

https://doi.org/10.3145/epi.2017.jul.14

\section{Introduction}

Political communication plays an essential role in the flow of communication between the various political actors. It has traditionally focused on the role of institutions, political parties and the media. However these political actors are being joined by new ones that perform activities with high impact on public policies. These arise from a double conjunction of gradual state ownership of society, and the socialisation of the State. This means that the decisions of institutions have significant bearing on social processes through norms and regulations, but at the same time, social organisations come together and participate in the implementation processes of public policies.

\subsection{Think tank concept}

"Think tank" is an English term that has been translated into Spanish as:

- tanques de pensamiento (tanks of thought)

- centros de investigación (research centres)

- laboratorios de ideas (laboratory of ideas)

The diversity of terms used to define think tanks allows the grouping of social organisations that research various topics, in order to present proposals that lead to political action. Those think tanks created from ideas and not for profit, in most cases, are defined by Castillo-Esparcia as:

"entities that, through research and analysis, put forward proposals for political action and direct or indirect communication strategies to influence public opinion" (Castillo-Esparcia, 2009).

For Rich (2004, p. 11), they are independent, non-political and non-profit organisations that, based on experience and ideas, try to influence, in particular, the process of policy making.

Stone (1996) also thinks that think tanks exert their influence on policy formulation:

- in a concrete sense, he defines this influence as its direct impact on legislation or the decisions of the government in particular;
- in a broader sense, this influence would be the power to change the consensus or to preserve the current climate of opinion.

Montobbio points out that think tanks, as political actors, share key characteristics that define them even more clearly when it comes to participating in political processes:

"Think tanks are an instrument of soft power, to argue, convince, and influence public opinion - directly or through the media - in other think tanks, government, institutions and actors of the political system involved in policy-making, as well as in other relevant national and international actors" (Montobbio, 2013, p. 22).

Stone (2007, pp. 4-14) has identified three roles of think tanks:

- to transmit knowledge and information among diverse actors in the political and social arena;

- to serve the public interest;

- to think ('think tanks think').

In think tank studies, almost all researchers agree that the concept is ambiguous, complex, and determined by several political factors in the system in which they are created. The researchers conclude that their definition always implies multiple and sometimes adverse consequences for empirical studies (Abelson 2001; 2006; Stone, 1996; McGann, 2014; Xifra, 2008; Medvetz, 2008). As Medvetz puts it:

"(...) the fundamental problem is that the central concept is fuzzy, mutable, and contentious. As Simon James aptly noted in 1998, 'Discussion of think tanks... has a tendency to get bogged down in the vexed question of defining what we mean by 'think tank' -an exercise which often degenerates into futile semantics'” (Medvetz, 2008, p. 1).

Recent definitions of think tanks are determined by the contextual aspects of social, political and cultural nature. These are so important in the present, and are the result of the political systems and institutional characteristics of these organisations. This contextual aspect shows that the most recent definitions have evolved alongside the systems in which they were established. According to Stone: 
"Think tanks are independent or private policy research organisations present in increasing numbers around the world. More often than not, think tanks are established as non-profit organisations. When they operate internationally, they are usually categorised as non-state actors in global and regional politics. Within the nation-state, they are more often described as third sector organisations emerging from civil society" (Stone, 2005, p. 2).

From the studies of Abelson (2001), Haass (2002) and Weaver (1989), three main periods can be identified, marking their progression from university, through advisory functions to government, to activism in the international arena:

a) Until the beginning of the XX century and within the framework of university research with a strictly investigative function in the pursuit of basic knowledge.

b) Since the Second World War, with focus on technical issues in warlike conflicts, and continuing within the framework of US hegemony in the international sphere.

c) The 1970s is the backdrop for the third evolutionary phase of these organisations, which result from the multiplication of national and international social organisations.

In the late 1960s, McGann, Viden, and Rafferty (2014, p. 21) found an expansion in both the number of think tanks and their ideological drive, specialisation, and level of politicisation. The ideas and the participants in this era are changing and debates start -on one hand about the integrity of public processes and debates, and on the other hand, about think tanks themselves, in reference to their independence, operational autonomy and academic freedom (McGann; Sabatini, 2011; McGann; Johnson, 2006; Stone; Denham, 2004; Stone; Denham; Garnett, 1998).

McGann and Weaver (2009) focus on the existence of four basic types of think tanks:

- Academic: university without students;

- Specialised research centres with contract researchers;

- Advocacy think tanks;

- Party think tanks.

To this classification Abelson (2006, pp. 47-48) adds two types:

- Policy clubs;

- Vanity or Legacy based think tanks.

\subsection{The role of communication in think tanks}

Taking these definitions of think tanks as a starting point, their power as an actor lies in "the formulation and promotion of ideas as a dominant paradigm" (Montobbio, 2013, pp. 14-15, p.18). The role of creation and participation in public debate does not only refer to the capacities of think tanks to configure or remodel it, but also in their role as interlocutor or idea broker (Smith, 1991; McGann; Viden; Rafferty, 2014), or as Urrutia points out:

"Creating a space for dialogue between governments and civil society and playing a mediating role. Equally, think tanks are conceived as strategic platforms for political parties "(Urrutia, 2013, p.1).

Wiarda (2008, p. 100) recognizes that this role of connec- ting research with politics is especially important, in what he calls knowledge broker. He considers the ability of think tanks to produce knowledge to be their source of public power:

"The think tanks thus perform liaison functions. They sift and filter the academic research for ideas that are useful and will 'fly' in a policy sense. (...) Then it is the job of the think tank scholars to translate the generally abstract prose in which academics write into terms that a policymaker can deal with. They must cut out the theory, the 'conceptual framework,' and the models and put the knowledge and information contained in the scholarly papers into concrete, practical language and recommendations" (Wiarda, 2008, p. 100).

Think tanks perform communication functions within their political roles (centred above all on influence) and social roles (education and information):

1. To be organisations that prepare and serve as recruitment centres for administration and government personnel, since they are accustomed to researching and working on issues that affect organisations.

2. To be centres of convergence on certain topics and objectives that specialists investigate in depth. This gives them a growing specialisation in the fields in which they operate.

3. To generate research places by adding their own researchers and guests.

4. To evaluate the actions, programs and policies of government agencies.

5. To raise public awareness of certain issues upon publication of their investigations.

6. To train researchers and intellectuals through courses. Some think tanks organise graduate programs aimed at intellectuals and future politicians.

7. To propose and advise on the formation and formulation of immediate public policies of governmental action.

8. To serve as centres of ideas and proposals for action in the medium and long term.

9. To defend the ideological hypotheses of the entity through reports and studies.

The think tanks also carry out communications and public relations activities: dissemination of scientific outputs, organisation of events (conferences, workshops, seminars, and briefings), media appearances, presentations, networking and exchange, and support for the creation and expansion of talented human resources (McGann; Johnson, 2006; Castillo-Esparcia; Almansa-Martínez; Smolak-Lozano, 2015). Stone indicates that these also adopt a protective role of the democratic system:

"It is not unusual to see some think tanks adopt the mantle of protectors of the principles and philosophies underlying democratic societies. Furthermore, it is often in their interests to do so, especially when seeking grants or aid from foundations or foreign donor agencies keen to promote civil society development" (Stone, 2007, p. 162). 
Parrilla, Almiron and Xifra warn that:

"The lack of transparency with regard to private donations, exhibited by the largest think tanks with the greatest capacity to exert influence cannot be ignored".

Think tanks "are consistently linked with political (government and party) actors, economics actors, academics and, to a lesser extent, the media" (Parrilla; Almiron; Xifra, 2016, p. 355).

In this sense, this research seeks to determine the presence of Spanish think tanks in the media and the degree of media exposure to their communicative strategies.

\section{Methodology}

We will analyse the presence of think tanks in the media as one of their communication activities. Media presence provides the possibility to stand as reference actors, and to obtain a mark of specialisation in a specific subject. This in essence allows them to be legitimate players in the formulation and formation of public opinion in relevant issues, which are the subject of public discussion.

In order to carry out the media analysis, the decision was made to study the presence of think tanks in the main Spanish newspapers since these are one of the sources of information for social, political and economic elites. As such, six general information ( $E$ l país, $A B C$, El mundo, La vanguardia, El periódico de Catalunya and La razón) and two economic information newspapers (Expansión and Cinco días) have been revised. A total of 33 think tanks were analysed that cover all those that maintain media presence and have an organised communication structure.

A period of five years was studied: from 2012 to 2016, accounting for the presence of think tanks in any editorial area and in any of the journalistic formats (information, opinion, reports, chronicles, etc.). The result is 8,493 journalistic spaces in the eight newspapers cited. The 4 objectives have been:

01: To find out the newspaper that most echoes the activities of think tanks.

O2: To discover which think tanks have greater media presence.

O3: To study the journalistic genres with more insights on the actions of think tanks, whether it be news, opinion or interviews.

04: To analyse the type of activity of think tanks with more newspaper presence, such as the presentation of documents, organisation of events, holding of conferences, awarding of prizes..

These objectives allow the creation of an x-ray of the presence of think tanks in Spanish newspapers, the degree of exposure of each medium and the type and modality of the communicative activity of think tanks.

\section{Results}

Table 1 shows the number of occurrences of the 33 think tanks taken into account in the newspapers analysed.
Faes (Foundation for Analysis and Social Studies) is the think tank with the largest presence in the newspapers analysed with 1,682 spaces, followed by Funcas with 1,666 and Circulo de Economía (812). There is an overwhelming control of those dedicated to the analysis of economy from an exclusively business perspective, since 6 of the first 10 have been created by entrepreneurs or financed by big companies like Funcas (Foundation of the Savings Banks), Circulo de Economía, Instituto de Estudios Económicos, Fedea (Foundation for the Study of Applied Economics), Círculo de Empresarios and Cotec. Likewise, in the top ten we find two think tanks analysing the social perspective from a conservative point of view (Faes) and progressive dimension (Fundación Alternativas). Finally, the Real Instituto Elcano is also present, specialising in the analysis of the international situation.

Of the 33 think tanks, the majority (12) specialise in multiple topics, or are generalists. Eleven focus their activity on the analysis of economic reality and make proposals in this field, 7 analyse the international context and 3 are associated with political and social behaviours.

The newspaper providing most media coverage of the think tanks analysed is El país with 2,496 spaces (30\% of all information collected). The second is the $A B C$ newspaper with 1,628 texts ( $19.16 \%$ of the total) and the third is the economic newspaper Expansión with 994 articles (11.7\%).

If we look at the three main think tanks that appear in the newspapers we find the following data:

- El país: Funcas, Faes and Real Instituto Elcano.

- ABC: Faes, Funcas and Instituto de Estudios Económicos.

- El mundo: Faes, Funcas and Real Instituto Elcano.

- La vanguardia: Funcas, Cidob and Círculo de Economía.

- El periódico de Cataluña: Funcas, Instituto de Estudios Económicos, Cidob.

- La razón: Faes, Círculo de Economía and Real Instituto Elcano.

- Expansión: Funcas, Círculo de Economía and Faes.

- Cinco días: Funcas, Faes and Instituto de Estudios Económicos.

Economic think tanks have a permanent and constant newspaper presence. So we find Funcas, Círculo de Economía and Instituto de Estudios Económicos, shaping a communicative ecosystem with a constant societal presence through their newspaper appearances.

One of the inherent elements of think tanks is the degree of specialisation of their research, so their presence in the newspapers is to provide opinions as experts on the pertinent topics. In consequence, those who have the highest percentage of participation with opinion or analysis articles are Fundación Alternativas, Cidob and Fride with about 33\% of their appearances in the newspapers.

Exploiting the legitimacy of the newspaper to expose positions and analyses as experts gives these think tanks the ability to be consulted on the topic they analyse and to be representative of that field. In this sense, out of the three think tanks that achieved greater presence as experts, two 
Table 1. Distribution of news from think tanks in each newspaper

\begin{tabular}{|c|c|c|c|c|c|c|c|c|c|}
\hline Think tanks & $A B C$ & El mundo & El país & $\begin{array}{c}\text { La } \\
\text { vanguardia }\end{array}$ & $\begin{array}{c}E I \\
\text { periódico }\end{array}$ & La razón & Expansión & $\begin{array}{l}\text { Cinco } \\
\text { días }\end{array}$ & Total \\
\hline Centre d'Estudis Jordi Pujol & 3 & 1 & 1 & 10 & 6 & 2 & - & - & 23 \\
\hline $\begin{array}{l}\text { Centro de Estudios Políticos y } \\
\text { Constitucionales }\end{array}$ & 44 & 40 & 45 & 10 & 13 & 41 & 7 & - & 200 \\
\hline $\begin{array}{l}\text { Centro Internacional de Toledo } \\
\text { para la Paz }\end{array}$ & 7 & 6 & 41 & 4 & 4 & 10 & 3 & - & 75 \\
\hline Cidob & 11 & 4 & 64 & 78 & 36 & & 5 & & 198 \\
\hline Círculo de Economía & 78 & 86 & 235 & 45 & 19 & 138 & 157 & 54 & 812 \\
\hline Círculo de Empresarios & 72 & 17 & 70 & 9 & 5 & 10 & 37 & 37 & 257 \\
\hline Civismo & 33 & 31 & 5 & 1 & 1 & 6 & 27 & 6 & 110 \\
\hline Cotec & 47 & 23 & 37 & 6 & 2 & 25 & 23 & 45 & 208 \\
\hline Faes & 435 & 202 & 444 & 29 & 30 & 322 & 133 & 87 & 1,682 \\
\hline Fedea & 74 & 37 & 210 & 22 & 8 & 35 & 72 & 46 & 504 \\
\hline Fundación Alternativas & 39 & 16 & 171 & 10 & 4 & 7 & 5 & 3 & 255 \\
\hline Fundación Ciudadanía y Valores & 20 & 7 & 3 & 3 & - & - & - & 1 & 34 \\
\hline Fundación Cultura de Paz & 6 & 2 & 19 & 5 & 3 & 13 & - & & 48 \\
\hline Ecodes & 15 & 3 & 24 & 17 & 2 & 5 & 4 & 4 & 74 \\
\hline $\begin{array}{l}\text { Fundación de Estudios Finan- } \\
\text { cieros }\end{array}$ & 4 & 7 & 9 & 9 & 7 & 8 & 45 & 6 & 95 \\
\hline Fundación Euroamérica & 4 & 2 & 13 & 3 & 3 & 2 & 9 & 2 & 38 \\
\hline Fundación Innovación Bankinter & 2 & 3 & 14 & 1 & 6 & 2 & 15 & 12 & 55 \\
\hline Funcas & 296 & 95 & 461 & 171 & 108 & 108 & 215 & 212 & 1,666 \\
\hline Fundación Ortega-Marañón & 5 & - & 36 & 1 & 12 & 4 & 1 & 1 & 60 \\
\hline Fride & 13 & 17 & 40 & 1 & 5 & 19 & 1 & - & 96 \\
\hline Fundación Sistema & 6 & 7 & 13 & 6 & 1 & 4 & 6 & - & 43 \\
\hline lecah & 2 & 6 & 60 & 6 & - & - & - & - & 74 \\
\hline Instituto Estudios Democracia & 12 & - & - & - & - & 1 & 1 & - & 14 \\
\hline Instituto de Estudios Económicos & 191 & 54 & 79 & 39 & 48 & 79 & 102 & 67 & 659 \\
\hline Instituto Estudios Fiscales & 18 & 13 & 67 & 9 & 24 & 10 & 26 & 26 & 193 \\
\hline Instituto de Estudios Riojanos & 13 & & 4 & 8 & - & - & - & - & 25 \\
\hline $\begin{array}{l}\text { Instituto Europeo del Mediterrá- } \\
\text { neo }\end{array}$ & 14 & 6 & 11 & 10 & 5 & 5 & - & - & 51 \\
\hline Institución Futuro & 3 & 2 & & 3 & - & - & - & - & 8 \\
\hline $\begin{array}{l}\text { Instituto Gobernanza Democrá- } \\
\text { tica }\end{array}$ & 4 & 13 & 23 & 3 & - & - & - & - & 43 \\
\hline Instituto Juan de Mariana & 25 & 15 & 7 & 10 & - & - & 14 & - & 71 \\
\hline $\begin{array}{l}\text { Instituto Universitario Gutiérrez } \\
\text { Mellado }\end{array}$ & 1 & 2 & 12 & 7 & - & - & - & - & 22 \\
\hline $\begin{array}{l}\text { Observatorio Nacional } \\
\text { Telecomunicaciones y SI }\end{array}$ & 24 & 10 & 26 & 10 & 1 & 2 & 18 & 12 & 103 \\
\hline Real Instituto Elcano & 107 & 82 & 252 & 36 & 12 & 119 & 68 & 21 & 697 \\
\hline Total & 1,628 & 809 & 2,496 & 582 & 365 & 977 & 994 & 642 & 8,493 \\
\hline Percentages & 19.17 & 9.53 & 29.39 & 6.85 & 4.30 & 11.50 & 11.70 & 7.56 & 100 \\
\hline
\end{tabular}


Table 2. Actions generating the information

\begin{tabular}{|c|c|c|c|c|c|c|c|c|c|c|c|}
\hline Think tanks & Opinion & Events & Studies & $\begin{array}{l}\text { Inaugu- } \\
\text { rations }\end{array}$ & $\begin{array}{l}\text { Confer- } \\
\text { ences }\end{array}$ & $\begin{array}{l}\text { Appoint- } \\
\text { ments }\end{array}$ & Awards & $\begin{array}{l}\text { Inter- } \\
\text { views }\end{array}$ & Meetings & Other & Total \\
\hline Centre d'Estudis Jordi Pujol & - & 1 & 15 & 1 & 3 & - & 1 & - & 2 & - & 23 \\
\hline $\begin{array}{l}\text { Centro de Estudios Políticosy } \\
\text { Constitucionales }\end{array}$ & 26 & 9 & 76 & 9 & 16 & 16 & 25 & 12 & 9 & 2 & 200 \\
\hline $\begin{array}{l}\text { Centro Internacional de } \\
\text { Toledo para la Paz }\end{array}$ & 19 & 12 & 28 & - & 12 & - & - & 2 & - & 2 & 75 \\
\hline Cidob & 62 & 1 & 98 & 12 & 18 & - & - & 2 & - & 5 & 198 \\
\hline Círculo de Economía & 42 & 11 & 569 & - & 112 & - & - & 46 & 29 & 3 & 812 \\
\hline Círculo de Empresarios & 21 & 49 & 59 & - & 75 & 3 & 30 & 18 & - & 2 & 257 \\
\hline Civismo & 4 & 21 & 32 & - & 22 & 5 & 5 & 5 & 15 & 1 & 110 \\
\hline Cotec & 39 & & 93 & 11 & 22 & - & - & 29 & 11 & 3 & 208 \\
\hline Faes & 217 & 290 & 316 & 10 & 369 & - & - & 32 & 409 & 39 & 1,682 \\
\hline Fedea & 31 & 41 & 185 & - & 89 & - & - & 16 & 36 & 106 & 504 \\
\hline Fundación Alternativas & 86 & 16 & 95 & - & 14 & - & - & 21 & 14 & 9 & 255 \\
\hline $\begin{array}{l}\text { Fundación Ciudadaníay } \\
\text { Valores }\end{array}$ & 2 & 10 & 10 & - & 10 & - & - & 1 & - & 1 & 34 \\
\hline Fundación Cultura de Paz & 1 & 10 & 10 & - & 13 & - & - & 3 & 10 & 1 & 48 \\
\hline Ecodes & 2 & 13 & 29 & 2 & 10 & - & - & 1 & 10 & 7 & 74 \\
\hline $\begin{array}{l}\text { Fundación de Estudios } \\
\text { Financieros }\end{array}$ & 9 & 12 & 45 & 3 & 10 & - & - & 2 & 13 & 1 & 95 \\
\hline Fundación Euroamérica & 2 & 10 & 5 & - & 10 & - & 4 & 1 & 4 & 2 & 38 \\
\hline $\begin{array}{l}\text { Fundación Innovación } \\
\text { Bankinter }\end{array}$ & 1 & 5 & 27 & - & 5 & - & - & 1 & 10 & 6 & 55 \\
\hline Funcas & 209 & 17 & 596 & - & 303 & - & - & 17 & 266 & 258 & 1,666 \\
\hline Fundación Ortega-Marañón & 5 & 10 & 25 & - & 8 & - & - & - & 10 & 2 & 60 \\
\hline Fride & 32 & 10 & 15 & - & 17 & - & - & 2 & 20 & - & 96 \\
\hline Fundación Sistema & 12 & 10 & 11 & - & 10 & - & - & - & - & - & 43 \\
\hline lecah & 15 & 13 & 20 & - & 13 & - & 2 & 1 & 9 & 1 & 74 \\
\hline $\begin{array}{l}\text { Instituto de Estudios } \\
\text { Democracia }\end{array}$ & 1 & 2 & 6 & - & 5 & - & - & - & - & - & 14 \\
\hline $\begin{array}{l}\text { Instituto de Estudios } \\
\text { Económicos }\end{array}$ & 39 & 113 & 287 & 29 & 57 & - & 19 & 14 & 45 & 56 & 659 \\
\hline Instituto de Estudios Fiscales & 30 & 20 & 109 & - & 4 & - & 8 & 17 & 4 & 1 & 193 \\
\hline Instituto de Estudios Riojanos & 1 & 5 & 11 & 2 & 2 & - & - & 1 & 2 & 1 & 25 \\
\hline $\begin{array}{l}\text { Instituto Europeo del } \\
\text { Mediterráneo }\end{array}$ & 1 & 5 & 36 & 2 & 2 & - & - & 2 & 2 & 1 & 51 \\
\hline Institución Futuro & & 1 & 5 & 1 & & - & - & 1 & - & - & 8 \\
\hline $\begin{array}{l}\text { Instituto Gobernanza } \\
\text { Democrática }\end{array}$ & 6 & 6 & 26 & 1 & 1 & - & - & 1 & - & 2 & 43 \\
\hline Instituto Juan de Mariana & 11 & 3 & 46 & 1 & 5 & - & - & 1 & 1 & 3 & 71 \\
\hline $\begin{array}{l}\text { Instituto Universitario } \\
\text { Gutiérrez Mellado }\end{array}$ & 1 & - & 20 & - & - & - & - & - & 1 & - & 22 \\
\hline $\begin{array}{l}\text { Observatorio Nacional } \\
\text { Telecomunicaciones y SI }\end{array}$ & 14 & 6 & 59 & 7 & 7 & - & - & 1 & 5 & 4 & 103 \\
\hline Real Instituto Elcano & 24 & 56 & 207 & 21 & 170 & - & - & - & 78 & 141 & 697 \\
\hline Total & 965 & 788 & 3,171 & 112 & 1,414 & 24 & 94 & 250 & 1,015 & 660 & 8,493 \\
\hline Percentages & 11.36 & 9.28 & 37.34 & 1.32 & 16.65 & 0.28 & 1.11 & 2.94 & 11.95 & 7.77 & 100 \\
\hline
\end{tabular}


are specialised (Cidob in international relations and Fride in national and international defense) and one has more general objectives (Fundación Alternativas).

However, the most widely used genre is the generation of news about their analysis and policy proposals, and the conferences or events they organise. Such news are their channels of information to communicate their proposals to the elite, but also to society, through the power of media irradiation.

The activities that can lead to the presence of think tanks in the newspapers can be classified into three main groups:

- participation in articles of analysis as experts on the topic of the think tank;

- organisation of events (conferences, prises, meetings);

- presentation of studies and analysis.

The latter is the most used and the one that allows them to transmit their main contributions to society through communications, conferences, and press conferences. In these studies, they discuss public affairs based on their own politico-ideological origins, especially the more generalist ones such as Faes, Fundación Alternativas, Fundación Sistema. Economic think tanks also transmit their ideologies, such as Círculo de Economía, Círculo de Empresarios, Fundación de Estudios Financieros, Instituto de Estudios Económicos, among others.

\section{Discussion}

From the analysis of the Spanish think tanks that appear in the reference newspapers, it appears that there is an elite that monopolises much of this media presence. Thus, we observe that Faes (with 1,682), Funcas $(1,666)$, Círculo de Economía (812), Instituto de Estudios Económicos (659) and Real Instituto Elcano (697) assume 65\% of all information, opinions and reports on studies and activities of think tanks. Of these five, three are dedicated exclusively to the analysis of the economic reality, from the perspective of large companies and the business sector. This means that the economic reality in newspapers is described from very specific hypotheses (companies and entrepreneurs) and visions of these organisations that have a marked conservative character. If we add that the main Spanish think tank according to the number of appearances is Faes, which until a few weeks ago was an integral part of the Partido Popular, it results in very specific visions of the social and economic situation.

During our period of analysis (2012-2016), the economic crisis that began in 2008 was still in full force, and due to the greater weight of economic think tanks, it is essential to include a broader longitudinal study including crisis-free years.

It is possible that some think tanks with little presence in the media are used instead as a reference by the government. The information from Spanish think tanks most often published by the media are those on economic issues. Normally the researchers of these institutions are not only limited to presenting their studies, but also, they become expert voices on which the media rely to have an opinion on certain subjects (dominant paradigm of Montobbio, 2013).

A few think tanks appear prominently in every newspaper. Accordingly, Faes appears in the first three places of all the national newspapers, with the exception of La vanguardia and El periódico de Cataluña. Funcas appears in all but $L a$ razón.

The presence of the Spanish think tanks in the media takes place in the form of news about acts, conferences and organised events, unlike the Americans and British whose experts and members generally have a very active participation in the media. This indirect presence in Spain may be one of the reasons why a large part of Spanish public opinion does not know what a think tank is, or what their most outstanding works are. However, the presence of experts in the Spanish media, with opinion articles, is growing over the years.

The goal of think tanks is to configure and determine the boundaries that surround solutions and social problems. Hence their interest in having a presence in the media:

- proposing issues that should be the subject of public debate;

- determining the conceptual limits of problems based on their ideologies.

\section{Bibliography}

Abelson, Donald (2001). Do the think tanks matter? Asessing the impact of public policy intitutes. Montreal: McGillQueen's University Press. ISBN: 9780773523173

Abelson, Donald (2006). A Capitol idea. Think tanks and US Foreing Policy. Montreal: McGill-Queen's University Press. ISBN: 9780773531154

Castillo-Esparcia, Antonio (2009). "Relaciones públicas y 'think thanks' en América Latina: estudio sobre su implantación y acción". Razón y palabra, n. 70.

https://dialnet.unirioja.es/servlet/articulo?codigo=3103137

Castillo-Esparcia, Antonio; Almansa-Martínez, Ana; Smolak-Lozano, Emilia (2015). "East European think tanks in social media - Towards the model of evaluation of effective comunication/PR strategist: Case study analysis". Catalan journal of communication and cultural studies, v. 7, n. 2, pp. 231-250.

https://goo.gl/SozMCq

https://doi.org/10.1386/cjcs.7.2.231_1

Haass, Richard N. (2002). "Think tanks and US foreign policy: A policy-maker's perspective". US Department of State, v. 7, n. 3.

https://2001-2009.state.gov/s/p/rem/15506.htm

McGann, James (2014). 2013 Global go to think tanks index report. Philadelphia: University of Pennsylvania. https://goo.gl/DESHpi

McGann, James; Johnson, Erik (2006). Comparative think tanks, politics and public policy. Northampton, MA: Edgard Elgar Pub. ISBN: 9781843760221

McGann, James; Sabatini, Richard (2011). Global think tanks: Policy networks and governance. New York: Routledge. ISBN: 9780415779784 
McGann, James; Viden, Anna; Rafferty, Jillian (2014). How think tanks shape social development policies. Philadelphia: Pennsylvania University Press. ISBN: 9780812246018

McGann, James; Weaver, Kent (2009). Think tanks and civil societies: Catalysts for action. New Brunswick, NJ: Transaction Publishers. ISBN: 9780765809520

Medvetz, Thomas (2008). Think tanks as an emergent field. New York: The Social Science Research Council.

https://www.ssrc.org/publications/view/think-tanks-as-anemergent-field

Montobbio, Manuel (2013). La geopolítica del pensamiento: think tanks y política exterior. Madrid: Real Instituto El Cano.

https://goo.gl/w8M8yY

Parrilla, Ricard; Almiron, Núria; Xifra, Jordi (2016). “Crisis and interest: The political economy of think tanks during the great recession". American behavior scientist, v. 60, n. 3, pp. 340-359.

https://goo.gl/UnCYHv

https://doi.org/10.1177/0002764215613404

Rich, Andrew (2004). Think tanks, public policy and the politics of expertise. Cambridge, University Press. ISBN: 052183019X

Smith, James-Allen (1991). The idea brokers: Think tanks and the rise of the new policy elite. New York: The Free Press. ISBN: 0029295513

Stone, Diane (1996). Capturing the political imagination: Think tanks and the policy process. London and Portland: Frank Cass. ISBN: 9780714642635
Stone, Diane (2005). Think tank transnationalisation and non-profit analysis, advice and advocacy. University of Warwick, UK: Department of Politics and International Studies.

Stone, Diane (2007). "Recycling bins, garbage cans or think tanks? Three myths regarding policy analysis institutes". Public administration, v. 85, n. 2, pp. 259-278.

https://doi.org/10.1111/j.1467-9299.2007.00649.x

Stone, Diane; Denham, Andrew (eds.) (2004). Think tank traditions: Policy research and the politics of ideas. Manchester: Manchester University Press.

Stone, Diane; Denham, Andrew; Garnett, Mark (eds.) (1998). Think tanks across nations: A comparative approach. Manchester: Manchester University Press. ISBN: 9780719050541

Urrutia, Olivier (2013). "El papel de los think tanks en la definición y aplicación de las políticas y estrategias de defensa". Revista del Instituto Español de Estudios Estratégicos, n. 2, pp. 1-34. http://revista.ieee.es/index.php/ieee/article/download/88/82

Weaver, Kent (1989). "The changing world of think tanks". Political science and politics, v. 22, n. 3, pp. 563-578.

http://www.medientheorie.com/doc/weaver_changing_ worlds_of_think_tanks.pdf

Wiarda, Howard (2008). "The new powerhouses: Think tanks and foreign policy". American foreign policy interests, v. 30, n. 2 , pp. $96-117$.

https://goo.gl/77cepM

http://dx.doi.org/10.1080/10803920802022704

Xifra-Triadú, Jordi (2008). Els think tanks. Barcelona: Editorial UOC. ISBN: 8497887832

\section{Da visibilidad a tu trabajo depositándolo en e-LIS, el mayor repositorio internacional sobre biblioteconomía, documentación y comunicación}

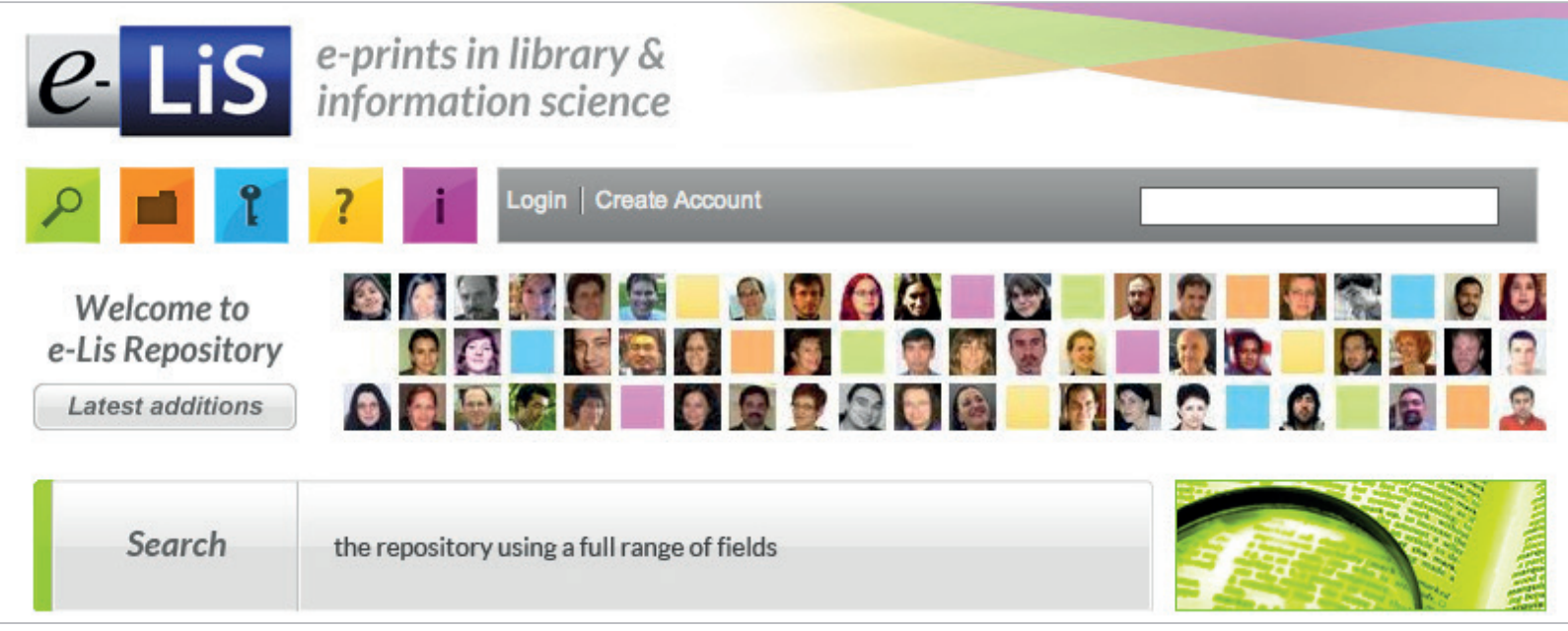

http://eprints.rclis.org 